\title{
Pengaruh Pengawasan Dan Disiplin Kerja Terhadap Produktivitas Karyawan PT. Kideco Jaya Agung
}

\author{
Shalahuddin*; Danang Alfian Saputra 2); Dedy Darmawan ${ }^{3)}$ \\ *Fakultas Ekonomi Jurusan Manajemen Universitas Borneo Tarakan \\ Jl. Amal Lama No. 1 Kel. Pantai Amal Kec. Tarakan Timur Kota Tarakan Kalimantan Utara \\ 2), 3) Jurusan Manajemen STIE Widya Praja Tanah Grogot \\ Jl. Jendral Sudirman No.149 Tanah Grogot Kabupaten Paser Kalimantan Timur \\ e-mail: shalahuddinayubi@,gmail.com
}

\begin{abstract}
This study aims to determine the effect of supervisory variables and Work Discipline on employee productivity in the Planning Department of PT Kideco Jaya Agung Batu Sopang District. The analytical tool used is multiple linear regression analysis which is processed with the help of SPSS. From the calculation results of the analysis shows that there is a very strong relationship between the variables of supervision and work discipline on employee productivity, while the coefficient of determination shows that the supervisory variable and the variable of work discipline provide an effect of $81 \%$ on employee productivity, while the remaining $19 \%$ is influenced by other variables that are not yet available in this research. The calculated $F$ value is illustrated that there is a joint effect between the supervisory variable and the work discipline variable on employee productivity. Likewise for the results of the t-test show that the supervisory variable has a dominant effect on employee productivity.
\end{abstract}

Keywords: Employee Productivity, Human Resource Management, Management, Supervision, Work Discipline

\begin{abstract}
Abstrak
Penelitian ini bertujuan untuk mengetahui pengaruh variabel pengawasan dan Disiplin Kerja terhadap produktivitas karyawan pada Departemen Planning PT Kideco Jaya Agung Kecamatan Batu Sopang. Alat analisis yang digunakan adalah analisis regresi linier berganda yang diolah dengan bantuan perangkat SPSS. Dari hasil perhitungan analisis memperlihatkan adanya hubungan yang sangat kuat antara variabel pengawasan dan disiplin kerja terhadap produktivitas karyawan, sedangkan koefisien determinasi menunjukkan bahwa variabel pengawasan dan variabel disiplin kerja memberikan pengaruh sebesar $81 \%$ terhadap produktivitas karyawan, sedangkan sisanya $19 \%$ dipengaruhi variabel lain yang belum terdapat dalam penelitian ini. Nilai F hitung tergambar bahwa terdapat pengaruh secara bersama-sama antara variable pengawasan dan variabel disiplin kerja terhadap produktivitas karyawan. Demikian juga untuk hasil uji t menunjukkan bahwa variabel pengawasan berpengaruh dominan terhadap produktivitas karyawan.
\end{abstract}

Kata kunci: Disiplin Kerja, Manajemen, Manajemen SDM, Pengawasan, Produktivitas Karyawan 


\section{PENDAHULUAN}

Dalam usaha pencapaian tujuan, setiap perusahaan harus didukung dengan adanya sumber daya manusia yang memiliki kompetensi dibidangnya. Untuk mencapai tujuan dan target perusahaan tersebut, diperlukan adanya pengawasan dan disiplin kerja yang baik sehingga menghasilkan produktivitas karyawan yang baik juga. Produktivitas karyawan berkaitan erat dengan sumber daya manusia (SDM) dan mempunyai peranan yang sangat penting dalam perusahaan untuk menciptakan pekerjaan yang berkualitas. Sumber daya manusia bukan hanya sekedar menjadi sumber daya, namun telah menjadi modal utama dalam mencapai keberhasilan, dimana dengan SDM yang berkualitas maka dapat menyelesaikan pekerjaannya secara maksimal.

Majunya sumber daya manusia saat ini didukung dengan bermunculannya teknologi yang modern, sehingga manusia dituntut untuk semakin berkompeten mengimbangi kemajuan peradaban dunia. Indonesia merupakan negara yang banyak mempunyai sumber energi. Sumber energi yang dimiliki dimanfaatkan secara optimal untuk meningkatkan kesejahteraan rakyat. Salah satu sumber energi yang ada adalah batubara. Batubara merupakan sumber energi yang menjadi primadona, baik di Indonesia maupun di negara-negara lain. Salah satu perusahaan yang bergerak pada sektor pertambangan batubara adalah PT Kideco Jaya Agung, yang lokasi penambangannya terletak di Desa Batu Kajang, Kecamatan Batu Sopang, Kabupaten Paser, Provinsi Kalimantan Timur.

Menurut (Manullang, 2012), "Pengawasan dapat diartikan proses untuk menerapkan pekerjaan apa yang sudah di laksanakan, menilainya dan bila perlu mengoreksinya dengan maksud supaya pelaksanaan pekerjaan sesuai dengan rencana semula". Pengawasan menjadi salah satu faktor penting dalam mempengaruhi produktivitas karyawan karena sebagai sarana kontrol kegiatan-kegiatan yang ada dalam sebuah perusahaan. Melalui pengawasan maka karyawan akan dapat diawasi dengan baik sehingga dapat meningkatkan disiplin kerja karyawan dan berdampak pada terwujudnya produktivitas karyawan secara maksimal.

Menurut (Hasibuan \& Hasibuan, 2016) "Kesadaran dan kesediaan seseorang menaati semua peraturan perusahaan dan normanorma sosial yang berlaku". Disiplin yang baik mencerminkan besarnya rasa tanggung jawab seseorang terhadap tugas-tugas yang diberikan kepadanya. Disiplin kerja karyawan yang tinggi sehingga mampu mencapai produktivitas karyawan yang maksimal, baik itu disiplin waktu, tata tertib atau peraturan yang telah ditetapkan oleh perusahaan.

Disiplin kerja dapat dilihat sebagai sesuatu yang besar manfaarnya, baik bagi kepentingan perusahaan maupun bagi karyawan. Manfaat disiplin kerja bagi perusahaan adalah menjamin terpeliharanya tata tertib dan kelancaran pelaksanaan tugas, sehingga diperoleh hasil yang optimal. (Mangkunegara, 2016) Manfaat disiplin kerja bagi karyawan yaitu diperoleh suasana kerja yang menyenangkan pekerjaannya. Disiplin karyawan adalah perilaku seseorang yang sesuai dengan peraturan, prosedur kerja yang telah ditentukan oleh perusahaan baik yang tertulis maupun tidak tertulis.

Pengawasan dan disiplin kerja diperlukan untuk mendidik, membimbing dan membina karyawan agar dapat bekerja secara efektif, efisien sehingga menghasilkan produktivitas karyawan yang baik bagi perusahaan. 
Menurut (Danang, 2015) "Produktivitas adalah ukuran yang menunjukkan pertimbangan antara input dan output yang dikeluarkan perusahaan serta peran tenaga kerja yang dimiliki persatuan waktu".Pada dasarnya pengawasan di Departemen Planning PT Kideco Jaya Agung sudah berjalan dengan baik, akan tetapi belum maksimal dan untuk disiplin kerja karyawan masih rendah yaitu masih terjadi penyimpangan-penyimpangan, baik terhadap disiplin kehadiran kerja, maupun terhadap tugas dan tanggung jawab pekerjaan yang diberikan oleh pimpinan. Hal tersebut yang mengakibatkan produktivitas karyawan tidak maksimal.Dengan pengawasan yang dilakukan secara intensif dan disiplin kerja yang terarah diharapkan dapat mambuat produktivitas karyawan menjadi lebih baik dalam menjalankan tugasnya, selama ini tindakan yang diambil oleh perusahaan melalui program tersebut dapat membantu karyawan dalam melaksanakan pekerjaannya.

Melalui pengawasan dan disiplin kerja yang lebih baik dapat meningkatkan produktivitas karyawan di Departemen Planning PT. Kideco Jaya Agung Kecamatan Batu Sopang. Hal ini juga bertujuan untuk menumbuhkan kembali rasa tanggung jawab pada masing-masing karyawan terhadap pekerjaannya sehingga dapat meningkatkan kualitas dan kuantitas produksi.

Adapun perumusan masalah di dalam penelitian ini yaitu Apakah variabel pengawasan dan disiplin kerja secara simultan maupun parsial berpengaruh signifikan terhadap produktivitas karyawan pada Departemen Planning PT Kideco Jaya Agung Kecamatan Batu Sopang serta Manakah diantara variabel pengawasan dan disiplin kerja yang berpengaruh dominan terhadap produktivitas karyawan pada
Departemen Planning PT Kideco Jaya Agung Kecamatan Batu Sopang Kabupaten Paser.

\section{TINJAUAN PUSTAKA}

Pengawasan merupakan satu diantara fungsi manajemen yang merupakan proses kegiatan pemimpin untuk memastikan dan menjamin bahwa tujuan dan tugas-tugas organisasi atau perusahaan dan telah terlaksana dengan baik sesuai dengan kebijakan, intruksi, rencana dan ketentuanketentuan yang berlaku. Menurut (Manullang, 2012) "Pengawasan adalah proses untuk menerapkan pekerjaan apa yang sudah dilaksanakan, menilainya dan bila perlu mengoreksinya dengan maksud supaya pelaksanaan pekerjaan sesuai dengan rencana semula". Dari pengertian tersebut dapat diambil kesimpulan bahwa pengawasan adalah suatu upaya agar yang telah direncanakan sebelumnya dapat diwujudkan serta untuk mengetahui kelemahan dan kesulitan dalam pelaksanaan pekerjaan, sehingga berdasarkan pengamatan-pengamatan tersebut dapat diambil suatu tindakan untuk memperbaikinya, demi tercapainya wujud semula. Jadi pimpinan perusahaan berperan penting dalam pengawasan dan itu berpengaruh besar terhadap bawahannya. Hal ini untuk menghindari kesalahan dan kegagalan yang dilakukan bawahannya dan dengan pengawasan tersebut dapat mencapai tujuan yang telah ditentukan oleh perusahaan.

Sedangkan tujuan utama dari suatu pengawasan adalah "Mengusahakan agar apa yang direncanakan menjadi kenyataan". (Manullang, 2012) Dari pengertian di atas dapat diambil kesimpulan bahwa pada hakekatnya tujuan pengawasan adalah mengamati pelaksanaan kegiatan dengan cara membandingkan hasil yang telah 
dicapai dengan apa yang harus dicapai sehingga penyimpangan-penyimpangan yang mungkin terjadi dapat ditanggulangi dengan memberikan koreksi dan pembinaan agar pelaksanaan tugas dapat terselenggara secara efektif dan efisien Menurut (Manullang, 2012) ada empat macam dasar penggolongan jenis pengawasan, yakni (1).Waktu Pengawasan, (2). Objek Pengawasan (3). Subjek Pengawasan (4). Cara mengumpulkan fakta-fakta guna pengawasan. Mengenai tugas dari pengawasan adalah bertujuan memperbaiki kualitas, hal yang tidak baik menjadi baik, mempertinggi rasa tanggung jawab bagi yang diberi tugas, pada dasarnya pengawasan merupakan kegiatan untuk memperbaiki, mendorong dan meningkatkan hasil dalam hal produktifitas karyawan.

Salah satu aspek yang perlu disoroti dalam manajemen sumber daya manusia adalah disiplin kerja. Menurut (Handoko, 2001) "Disiplin adalah kegiatan manajemen untuk menjalankan standar-standar organisasional". Kedisiplinan harus ditegakkan dalam suatu organisasi perusahaan. Tanpa dukungan disiplin karyawan yang baik, sulit perusahaan untuk mewujudkan tujuannya. Jadi, kedisiplinan adalah kunci keberhasilan suatu perusahaan dalam mencapai tujuannya. Perilaku disiplin karyawan merupakan sesuatuyang tidak muncul dengan sendirinya, tetapi perlu dibentuk. Ada beberapa tipe kegiatan pendisiplinan yang dapat dilakukan, yaitu (1.) Disiplin preventif adalah kegiatan yang dilaksanakan untuk mendorong para karyawan agar mengikuti berbagai standar dan aturan sehingga penyelewenganpenyelewengan dapat dicegah (2.) Disiplin korektif adalah kegiatan yang diambil untuk menangani pelanggaran terhadap aturanaturan dan mencoba untuk menghindari pelanggaran-pelanggaran lebih lanjut. (3.) Disiplin progresif adalah memberikan hukuman-hukuman yang lebih berat terhadap pelanggaran-pelanggaran yang berulang. (Handoko, 2001). Penegakan disiplin karyawan perlu dibarengi dengan konsekuensi atas pelanggaran atau penyelewengan agar karyawan bisa memaksimalkan kedisiplinannya. Hal ini perlu diterapkan agar perusahaan dapat mencapai produktivitas karyawan yang maksimal dan mencapai tujuan perusahaan.

Secara filosofi (Siagian, 2017) produktivitas merupakan sikap mental yang selalu berusaha dan mempunyai pandangan bahwa suatu kehidupan hari ini lebih baik dari hari kemarin dan hari esok lebih baik dari hari ini. Secara teknis produktivitas merupakan perbandingan antara hasil yang dicapai dan keseluruhan sumber daya yang diperlukan. Menurut (Danang, 2015) "Produktivitas adalah ukuran yang menunjukkan pertimbangan antara input dan output yang dikeluarkan perusahaan serta peran tenaga kerja yang dimiliki persatuan waktu". Produktivitas sering dibandingkan dengan standar yang sudah ditentukan sebelumnya. Apabila lebih banyak keluaran dihasilkan dari jumlah masukan yang sama, produktivitas diperbaiki. Suatu organisasi yang professional tidak akan mampu mewujudkan suatu manajemen kinerja yang baik tanpa ada dukungan yang kuat.

Menurut (Soetrisno, 2016) Produktivitas merupakan hal yang sangat penting bagi para karyawan yang ada di perusahaan. Dengan adanya produktivitas kerja diharapkan pekerjaan akan terlaksana secara efisien dan efektif, sehingga ini semua akhirnya sangat diperlukan dalam pencapaian tujuan yang sudah ditetapkan. Untuk mengukur produktivitas kerja, diperlukan suatu indicator (1.) Kemampuan. 
mempunyai kemampuan untuk melaksanakan tugas. Kemampuan seorang karyawan sangat bergantung pada keterampilan yang dimiliki serta profesionalisme mereka dalam bekerja. Ini memberikan daya untuk menyelesaikan tugas-tugas yang diembannya kepada mereka. (2) Meningkatkan hasil yang dicapai. Berusaha untuk meningkatkan hasil yang dicapai. Hasil merupakan salah satu yang dapat dirasakan baik oleh yang mengerjakan maupun yang menikmati hasil pekerjaan tersebut. Jadi, upaya untuk meningkatkan produktivitas kerja bagi masing-masing yang terlibat dalam suatu pekerjaan. (3) Semangat kerja. Ini merupakan usaha untuk lebih baik dari hari kemarin. Indikator ini dapat dilihat dari etos kerja dan hasil yang dicapai dalam suatu hari kemudian dibandingkan hari sebelumnya. (4) Pengembangan diri. Senantiasa mengembangkan diri untuk meningkatkan kemampuan kerja. Pengembangan diri dapat dilakukan dengan melihat tantangan dan harapan dengan apa yang akan dihadapi. Sebab semakin kuat tantangannya, pengembangan diri mutlak dilakukan. Begitu juga harapan untuk menjadi lebih baik pada gilirannya akan sangat berdampak pada keinginan karyawan untuk meningkatkan kemampuan. (5) Mutu. selalu berusaha untuk meningkatkan mutu lebih baik dari yang telah lalu.Mutu merupakan hasil pekerjaan yang dapat menunjukkan kualitas kerja seorang pegawai. Jadi, meningkatkan mutu bertujuan untuk memberikan hasil yang terbaik yang pada gilirannya akan sangat berguna bagi perusahaan dan dirinya sendiri. (6) Efisiensi. Perbandingan antara hasil yang dicapai dengan keseluruhan sumber daya yang digunakan. Masukan dan keluaran merupakan aspek produktivitas yang memberikan pengaruh yang cukup signifikan bagi karyawan”.

\section{Studi Pendahuluan}

Penelitian Rajab Abdul Kari Rambe dengan Judul Pengaruh Pengawasan dan Disiplin Kerja Terhadap Produktivitas Kerja Karyawan PT Perkebunan Nusantara XIII Unit Pabrik Minyak Sawit Semuntai Kecamatan Longikis dengan hasil $\mathrm{Y}=1,155$ $+0,709 \mathrm{X} 1+0,086 \mathrm{X} 2, \mathrm{R}=0,784, \mathrm{R} 2=$ $0,595 \mathrm{~F}$ hitung $=30,387 \mathrm{t}$ hitung $=\mathrm{X} 1=$ $6,068, \mathrm{X} 2=0,997 \mathrm{X} 1$ dominan yaitu 6,068.

Sedangkan Penelitian Muhammad Syaifullah dengan Judul Pengaruh Pengawasan dan Disiplin Kerja terhadap Kinerja Karyawan Pada Departemen Quality Control PT Kideco Jaya Agung Kecamatan Batu Sopang dengan hasil $\mathrm{Y}=1,454+0,426$ $\mathrm{X} 1+0,340 \mathrm{X} 2, \mathrm{R}=0,653, \mathrm{R} 2=0,426 \mathrm{~F}$ hitung $=12,244 \mathrm{t}$ hitung $=\mathrm{X} 1=3,447, \mathrm{X} 2=$ 1,559, X1 dominan yaitu 3,447.

Jadi kerangka berfikir merupakan yang dapat menjabarkan berbagai variabel yang akan diteliti kemudian membuat hubungan antara satu variabel dengan variabel yang lain, sehingga akan mudah dirumuskan masalah penelitian dan masalah penulisan, penelitian teori yang relevan, rumus hipotesis yang diajukan strategi penelitian yang akan digunakan serta kesimpulan yang diharapkan.

\section{METODE PENELITIAN}

\section{Jenis Penelitian}

Adapun penelitian ini yaitu kualitatif, dimana lokasi penelitian yaitu di PT Kideco Jaya Agung Kecamatan Batu Sopang pada bulan April sampai dengan bulan Mei 2019. Menurut (Sugiyono, 2008) "Populasi adalah wilayah generalisasi yang terdiri atas: objek/subjek yang mempunyai kuantitas dan karakteristik tertentu yang ditetapkan oleh peneliti untuk dipelajari dan kemudian ditarik 
kesimpulannya". Jadi populasi merupakan objek/subjek yang digunakan dalam penelitian sebagai sumber data. Populasi bukan hanya orang, tetapi juga objek dan benda-benda alam yang lain. Populasi juga bukan sekedar jumlah yang ada pada objek/subjek yang dipelajari, tetapi meliputi seluruh karakteristik/sifat yang dimiliki oleh subjek atau objek tersebut.

\section{Populasi dan sampel}

Populasi dalam penelitian ini adalah seluruh karyawan Departemen Planning PT Kideco jaya Agung Kecamatan Batu Sopang Kabupaten Paser yang berjumlah 39 orang karyawan yang berstatus sebagai karyawan tetap dan karyawan service contract pada PT Kideco Jaya Agung Kecamatan Batu Sopang. Sampel adalah bagian dari jumlah dan karakteristik yang dimiliki oleh populasi. sedangkan dalam menentukan jumlah sampel penelitian ini, peneliti menggunakan pedoman (Arikunto, 2019) yang menyatakan bahwa: "Apabila subjeknya kurang dari 100, lebih baik diambil semua sehingga penelitiannya merupakan penelitian populasi. Selanjutnya, jika jumlah subjeknya lebih dari 100, untuk teknik sampel berstrata, dengan besarnya sampel $20 \%$ populasi”. Berdasarkan pendapat tersebut, peneliti menggunakan sampel jenuh yaitu menetapkan sampel sejumlah populasi yang ada yaitu berjumlah 39 orang karyawan pada Departemen Planning PT Kideco Jaya Agung Kecamatan Batu Sopang.

\section{Metode analisis data}

Agar dalam penulisan ini dapat memberikan gambaran akan sifat kebenaran secara ilmiah dan dapat diuraikan secara sistematis, maka pengumpulan data dalam penelitian ini melalui (1) Penelitian Lapangan (field work research) Penelitian langsung ke lapangan atau objek penelitian untuk melihat dari dekat keadaan perusahaan guna memperoleh data primer yang digunakan melalui metode Observasi, Wawancara, Kuesioner. (2) Penelitian Kepustakaan Penelitian ini dilakukan dengan mempelajari literatur-literatur yang berkenaan dengan konsep pengawasan dan disiplin kerja, produktifitas karyawan baik dalam bentuk teori-teori maupun studi kasus dari sumber-sumber pustaka yang ada dan bersifat mendukung dan melengkapi.

Untuk keperluan analisis ini, penulis mengumpulkan dan mengolah data yang diperoleh dari kuesioner dengan cara memberikan bobot penilaian dari setiap pertanyaan. Didalam menganalisis dan pengijuan hipotesis sehubungan dengan permasalahan dalam penelitian ini, peneliti menggunakan statistik regresi linier berganda, analisis korelasi berganda, koefisien determinasi, perhitungan uji $\mathrm{F}$ dan uji t.

\section{HASIL DAN PEMBAHASAN}

Hasil

Setelah variabel dalam penelitian yang diuraikan, berikutnya adalah pembahasan teknik analisa data yang digunakan dalam penelitian ini. Berikut ini datanya (1) Uji Validitas Uji validitas digunakan untuk menguji masing-masing instrument yang ada dalam kuisioner, hal ini dilakukan untuk memperoleh alat pengukur yang valid. Dalam penentuan layak atau tidaknya suatu item yang digunakan, biasanya dilakukan uji signifikansi koefisien korelasi pada tingkat signifikansi 0,05. Artinya semua item dianggap valid jika korelasi signifikansi terhadap skor total. Selanjutnya, nilai $r$ hitung dibandingkan dengan nilai $r$ tabel dengan derajat bebas (n-2). Dari keterangan tersebut, maka dapat diketahui $r$ tabel adalah 
terletak pada kolom 39-2=37. Jika $\mathrm{r}_{\text {hitung }}>$ $r_{\text {tabel }}$ pada tingkat signifikan 0,05 maka berarti signifikan sehingga disimpulkan bahwa butir pertanyaan atau pertanyaan itu valid.

Dari analisis uji validitas diperoleh jumlah soal sebanyak 13 soal atau $r_{\text {hitung }}>r_{\text {tabel }}$ semua memiliki nilai $r_{\text {hitung }}$ yang lebih dari 0,316 , yang berarti dapat ditarik kesimpulan bahwa semua soal adalah valid.

Uji Reliabilitas Untuk selanjutnya adalah menguji kuisioner dengan menggunakan uji reliabilitas, hal ini dilakukan untuk menguji tingkat konsistensi dari masing-masing pertanyaan. Berdasarkan hasil pengujian reliabilitas dari keseluruhan variabel dalam penelitian ini diperoleh hasil sebagai berikut. Dari hasil uji reliabilitas pada tabel 1 tersebut dapat diketahui bahwa diperoleh hasil sebesar 0,866 yang berarti butir kuisioner tersebut dikatakan reliabel (layak) karena cronbach's alpha $>0,06$.

Maka langkah selanjutnya adalah melakukan analisis regresi linear berganda, karena variabel independen yang digunakan dalam penelitian ini ada 2, yang terdiri dari $\left(\mathrm{X}_{1}\right)$ dan $\left(\mathrm{X}_{2}\right)$ terhadap $(\mathrm{Y})$ Departemen Planning PT Kideco Jaya Agung. Adapun hasil analisis yang telah dilakukan tampak pada tabel 2 .

Tabel 1. Hasil Reliability Statistics

\begin{tabular}{|c|c|}
\hline Cronbach's Alpha & N of Items \\
\hline 0,866 & 13 \\
\hline
\end{tabular}

Sumber: Data diolah, 2019

Tabel 2. Hasil Analisis Regresi Linear Berganda

\begin{tabular}{|l|c|c|c|}
\hline Variabel & $\begin{array}{c}\text { Coeffisient } \\
\text { Regressions } \\
1.049\end{array}$ & $t_{\text {hitung }}$ & Sig \\
\hline Penstanta & 0.531 & 6.644 & 0.000 \\
\hline Disiplin Kerja $\left(\mathrm{X}_{2}\right)$ & 0.283 & 2.585 & 0.014 \\
\hline $\mathrm{R}^{2}$ (Koefisien determinasi) & & $=0.810$ \\
$\mathrm{R}$ (Koefisien korelasi) & $=0.906$ & \\
$\mathrm{~F}_{\text {hitung }}$ & $=82.156$ & \\
Sig F & & $=0.000$ & \\
$\mathrm{~F}_{\text {tabel }}$ & $=3.26$ & \\
$\mathrm{t}_{\text {tabel }}$ & & $=2.028$ & \\
$\mathrm{n}$ & & $=39$ & \\
\hline
\end{tabular}

Sumber: Data diolah, 2019

\section{Pembahasan}

Dari penelitian ini perhitungan persamaan regresi linear berganda pada tabel 2 menunjukkan persamaan $\mathrm{Y}=1,049+$ $0,531 X_{1}+0,283 X_{2}$, yang berarti bahwa: Angka 1,049 adalah nilai konstanta, yang berarti meskipun nilai pengawasan dan disiplin kerja adalah sama dengan 0, maka besarnya nilai variabel produktivitas kerja adalah 1,049. Angka 0,531 adalah nilai koefisien untuk variabel pengawasan, yang berarti jika variabel tersebut mengalami 
kenaikan sebesar 1 satuan dengan asumsi variabel lain tetap atau konstan maka nilai variabel terikat akan mengalami kenaikan sebesar 0,531. Angka 0,283 adalah nilai koefisien untuk variabel disiplin kerja, yang berarti jika variabel isiplin kerja mengalami kenaikan sebesar 1 satuan dengan asumsi variabel lain tetap atau konstan, maka nilai produktivitas kerja juga akan mengalami kenaikan sebesar 0,283. Berbeda dengan hasil penelitian yang dilakukan oleh Rajab Abdul Kari Rambe yang mendapatkan persamaan $\mathrm{Y}=1,155+0,709 \mathrm{X} 1+0,086 \mathrm{X} 2$ dan penelitian Muhammad Syaifullah dengan persamaan $\mathrm{Y}=1,454+0,426 \mathrm{X} 1+0,340 \mathrm{X} 2$ sehingga dapat dilihat perbedaan dari beberapa penelitian tersebut.

Selanjutnya dari hasil perhitungan koefisien korelasi (R) Dari tabel tersebut dapat diketahui nilai koefisien korelasi sebesar 0,906 yang berarti bahwa hubungan antara variabel $\left(\mathrm{X}_{1}\right)$ dan $\left(\mathrm{X}_{2}\right)$ terhadap variabel (Y) yaitu berada pada tingkatan 0,80-1,000. Di mana dalam buku (Sugiyono 2016), dapat diketahui bahwa pada tingkatan atau level tersebut maka hubungan antara kedua variabel yaitu variabel $\left(\mathrm{X}_{1}\right)$ dan $\left(\mathrm{X}_{2}\right)$ dengan variabel $(\mathrm{Y})$ adalah sangat kuat. Koefisien Determinasi $\left(\mathrm{R}^{2}\right)$ Dari tabel tersebut di atas, diketahui nilai koefisien determinasi sebesar 0,810 atau sebesar $81,0 \%$, yang berarti bahwa variabel yang diteliti telah memberikan kontribusi sebesar $81,0 \%$ terhadap variabel Produktivitas Karyawan. Sedangkan sisanya sebesar 19,0\% dipengaruhi oleh faktor lain yang belum diteliti dalam penelitian ini.

Uji F (Uji Serempak) Dari perhitungan uji $\mathrm{F}$ diketahui nilai $F_{\text {hitung }}$ sebesar 82,156 dan jika dibandingkan dengan $F_{\text {tabel }}$ sebesar 3,26. Jadi nilai $F_{\text {hitung }}>F_{\text {tabel }}$ atau nilai 82,156 $>$ 3,26 yang berarti bahwa variabel $\left(\mathrm{X}_{1}\right)$ dan variabel $\left(\mathrm{X}_{2}\right)$ berpengaruh signifikan secara bersama-sama (simultan) terhadap variabel (Y). Yang berarti bahwa hipotesis pertama diterima, atau $\mathrm{H}_{0}$ ditolak dan $\mathrm{H}_{\mathrm{a}}$ diterima. Uji $\mathrm{t}$ (Uji sendiri-sendiri) Setelah dilakukan uji t, maka diperoleh hasil sebagai berikut thitung untuk variabel $\left(\mathrm{X}_{1}\right)$ diperoleh hasil sebesar 6,644 dan jika dibandingkan dengan $t_{\text {tabel }}$ sebesar 2,028, maka thitung $>t_{\text {tabel }}$ atau nilai $6,644>2,028$ dengan nilai signifikan $0,000<$ 0,05 . Jadi variabel $\left(X_{1}\right)$ berpengaruh secara siginifikan terhadap variabel (Y). thitung untuk variabel $\left(\mathrm{X}_{2}\right)$ diperoleh hasil sebesar 2,585 dan jika dibandingkan dengan $t_{\text {tabel }}$ sebesar 2,028 , maka $t_{\text {hitung }}>t_{\text {tabel }}$ atau nilai 2,585 $>$ 2,028 dengan nilai signifikan $0,014<0,05$. Jadi variabel $\left(\mathrm{X}_{2}\right)$ berpengaruh secara signifikan terhadap variabel (Y). Dari apa yang telah diuraikan tersebut, maka diketahui untuk hipotesa kedua juga terbukti, yaitu variabel $\left(\mathrm{X}_{1}\right)$ yang dominan berpengaruh terhadap variabel (Y) ini dibuktikan dengan nilai thitung tertinggi yaitu sebesar 6,644 dan dengan nilai signifikan terkecil 0,000 atau $\mathrm{H}_{0}$ ditolak dan $\mathrm{H}_{\mathrm{a}}$ diterima.

\section{KESIMPULAN DAN SARAN}

\section{Kesimpulan}

Dari hasil penelitian yang telah peneliti dapatkan bahwa pengawasan mempengaruhi produktivitas karyawan pada departemen planning PT Kideco Jaya Agung, artinya semangkin baik pengawasan akan berdampak terhadap produktivitas karyawan yang tentunya akan berdampak pada kemajuan perusahaan. Demikian juga dengan disiplin kerja berpengaruh positif terhadap produktivitas kerja, hal ini sejalan dengan penelitian sebelumnya yang meyatakan bahwa disiplin berpengaruh secara positif terhadap produktivitas kerja karyawan. Kedua, bahwa perhitungan nilai koefisien korelasi mengambarkan nilai yang positif dapat dijelaskan bahwa terdapat hubungan 
yang kuat antara pengawasan dan disiplin kerja terhadap produkltivitas karyawan, artinya bahwa hubungan keduanya saling searah. Korelasi positif, menunjukkan kenaikan pada pengawasan dan disiplin kerja diikuti oleh kenaikan produktivitas karyawan pada departemen planning PT Kideco Jaya Agung. Selain itu, Nilai koefisien determinasi menunjukkan bahwa variabel yang diteliti telah memberikan kontribusi besar terhadap variabel produktivitas karyawan, sedangkan sisanya dipengaruhi oleh variabel lain yang belum diteliti dalam penelitian ini.

\section{Saran}

Penelitian ini masih banyak keterbatasan diantaranya jumlah sampel yang masih relative sedikit jika dibandingkan dengan jumlah karyawan yang ada dalam perusahaan dan juga masih terdapat indikator instrument yang masih memiliki derajat yang lebih akurat dalam mengukur pengawasan dan disiplin kerja serta produktivitas kerja pada PT. Kideco Jaya Agung. Untuk peneliti lain agar dapat menambah variabel lainnya yang mempengaruhi produktivitas karyawan, karena masih adanya variabel yang belum diteliti oleh peneliti sehingga dapat menambah wawasan dan menujang ilmu pengetahuan khususnya yang berkaitan dengan manajemen sumber daya manusia.

\section{DAFTAR PUSTAKA}

Arikunto, S. J. J. R. C. (2019). Prosedur Penelitian Suatu Pendekatan Praktik (Edisi Revisi 2019).

Danang, S. J. Y. C. (2015). Penelitian Sumber Daya Manusia (Teori, Kuesioner, Alat Statistik, dan Contoh Riset).

Handoko, T. H. J. Y. B. (2001). Manajemen personalia dan sumber daya manusia, edisi kedua.
Hasibuan, M. S., \& Hasibuan, H. M. S. (2016). Manajemen sumber daya manusia: Bumi Aksara.

Mangkunegara, A. A. P. (2016). Manajemen sumber daya manusia perusahaan: PT. Remaja Rosdakarya.

Manullang, M. (2012). Dasar-Dasar Manajemen (Cetakan keduapuluh dua). In: Gadjah Mada University Press. Yogyakarta.

Rambe, Rajab Abdul Kari. (2014). Pengaruh Pengawasan dan Disiplin Kerja Terhadap Produktifitas Kerja Karyawan Pada PTP Nusantara XIII (Persero) Unit Pabrik Minyak Sawit Semuntai Kecamatan Long Ikis. Program Studi Manajemen. STIE Widya Praja. Tanah Grogot.

Siagian, S. P. (2017). Manajemen sumber daya manusia: Bumi Aksara.

Soetrisno, E. (2016). Manajemen sumber daya manusia: Kencana.

Sugiyono. (2008). Metode penelitian pendidikan:(pendekatan kuantitatif, kualitatif dan $R \& D$ ): Alfabeta.

Syaifullah, Muhammad. (2015). Pengaruh Pengawasan dan Disiplin Kerja Terhadap Kinerja Karyawan pada Departemen Quality Control PT Kideco Jaya Agung Kecamatan Batu Sopang. Program Studi Manajemen. STIE Widya Praja. Tanah Grogot. 